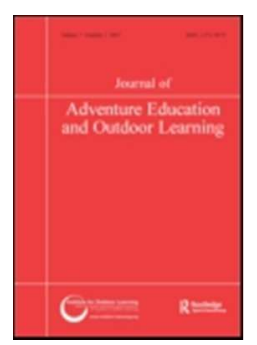

\title{
Enacting a place-responsive research methodology: walking interviews with educators
}

\begin{tabular}{|r|l|}
\hline Journal: & Journal of Adventure Education \& Outdoor Learning \\
\hline Manuscript ID & RAOL-2014-0040.R2 \\
\hline Manuscript Type: & Original Article \\
\hline Keywords: & $\begin{array}{l}\text { Place, place-responsive, walking interview, mobile methodology, outdoor } \\
\text { learning, outdoor education }\end{array}$ \\
\hline \multicolumn{2}{|l}{} \\
\hline
\end{tabular}

SCHOLARONE $^{\mathrm{S}}$
Manuscripts

URL: http://mc.manuscriptcentral.com/raol 


\title{
Enacting a place-responsive research methodology: walking interviews
} with educators

\author{
Place-based and place-responsive approaches to outdoor learning and education \\ are developing in many countries but there is dearth of theoretically-supported \\ methodologies to take a more explicit account of place in research in these areas. \\ In response, this paper outlines one theoretical framing for place-responsive \\ methodologies for researching outdoor learning and education. We exemplify \\ how this might work in practice with data and analysis from one suggested place- \\ responsive research method, the walking interview. Implications and \\ consequences for how outdoor learning might be researched more widely are \\ explored.
}

\begin{abstract}
Keywords: Place, place-responsive, walking interview, mobile methodology, outdoor learning, outdoor education.
\end{abstract}

\section{Introduction}

In this article we provide viable theoretical bases for the expression of a placeresponsive research methodology. We exemplify what this might mean in practice with a description of one place-responsive research method - the walking interview - and a commentary on how this approach generated data and led to data analysis. We argue that the development of a more place-responsive research methodology is now required as a deeper concern for place becomes more important in expressions of the purposes and practices of outdoor and environmental education (Brookes, 2002; Brown, 2012; Quay and Seaman 2013; Somerville et al, 2009, 2011; Stewart, 2008; Cameron, 2003, Mannion, et al 2011). Our contribution sits within a wider burgeoning concern for the importance of place and mobilities in the social sciences (Cameron, 2003; Casey, 1998, 
Thrift, 1999; Urry 2007). Indeed, walking itself, is receiving renewed attention in geography and anthropology as both a social practice and as a research method (Edensor, 2010; Ingold and Vergunst, 2008; Ingold, 2010,) but its application in placebased and place-responsive outdoor and environmental education remains unaired.

We will start by describing how outdoor education and outdoor learning fields are increasingly considering place as a key concern. We will delineate what we mean by a place-responsive methodology. Within this methodology, we describe the walking interview as one example method. In this paper we share three data examples wịth analysis, as 'vignettes' produced through this approach. The walking interviews with teachers allowed the researcher to take respondents back to the places that both inspired their plans for teaching outdoors and the places they subsequently visited with their learners. Walking interviews are but one of a possible wider set of methods that could be used to operationalize place-responsiveness in research and we hope that our contribution will encourage further flourishing of new methods and methodological orientations to place which has been a long-standing concern for readers of this journal and beyond. We close by summarising what we consider to be the implications of taking seriously these key aspects of a place-responsive disposition to research for the field of educational research generally and for outdoor, environmental, adventure and experiential learning in particular.

\section{Place: a preeminent concern}

Within the field of outdoor education and learning, 'place' has become a preeminent concern (Mannion and Lynch, 2016; Quay and Seaman 2013). Writing across a wide variety of approaches researchers and theorists are currently taking greater account of the importance of place in learning and education outdoors (Ballantyne and Packer, 
2002, 2006, 2009; Beames, Higgins and Nicol, 2012; Bentsen, Mygind and Randrup, 2009; Brookes, 2002; Harrison, 2010; Higgins and Wattchow, 2012; Mannion, Fenwick and Lynch, 2013; Mygind, 2009; Somerville et al, 2009, 2011; Stewart, 2008; Waite 2011; Wattchow and Brown, 2011).

Place-based education in particular exemplifies this concern with place (Gruenewald, 2003a, 2003b; Harrison 2010; Woodhouse and Knapp 2000). Place-based education brings together concerns found within strands of environmental education, critical pedagogy and outdoor and experiential education. It has been developed within a variety of orientations; from a psychological and place-attachment approach (Ardoin, 2006, 2012), to critical approaches to globalisation (Gruenewald and Smith, 2008), and a concern with local politics and 'connectedness' to the local community (Meichtry and Smith, 2007; Smith and Sobel, 2010). Place-based education is not without its critics, there are concerns around how 'place' is defined, whose 'notion' of place takes precedent, and how these come about. Nespor (2008) notes that place-based education has, at times, overly-simplified notions of community and place. Mannion and Lynch (2016) consider all three problems and advocate a less anthropocentric approach to place wherein social and ecological aspects are entwined. They ask "in what ways can place-responsiveness be a reciprocal eco-social process involving humans and other entities?" (Mannion and Lynch, 2016, 90).

Despite the rhetoric around place, only a small number of empirical studies have taken place as a target central concern. In Australia, a country of contrasted histories of place between the modern and the indigenous populations, Brookes (2002) and Stewart (2004) explore the role of place in meaning making in outdoor experiences. Stewart (2004) has noted how different epistemological and ontological facets of experiences in the outdoors can result in different understanding of places. Ballantyne and Packer

\section{URL: http://mc.manuscriptcentral.com/raol}


$(2002 ; 2006 ; 2009)$ have identified the importance of place as a context for sensory engagement in teaching strategies outdoors. Tooth and Renshaw, (2009) extend this to show that outdoor learning pedagogy should be more attentive to place, especially in educating for sustainability. In New Zealand, researchers are acknowledging the changing global environment and the importance of pedagogy that includes place (Cosgriff, et al 2012; Brown, 2012).

The way places are responded to by teachers is also seen as increasingly important. In Sweden, Szczepanski (2012) provides an analysis of teachers' perceptions of outdoor practice showing, inter alia, that they afford eventful opportunities for free discovery and sensory experience. Research on 'Udeskole' in Denmark has found that natural settings were a catalyst for pedagogical change in teachers' approaches (Bentsen et al, 2009; Mygind, 2009). In a Scottish context, when teachers' took their outdoor learning into natural nature reserves, it was found that teachers' curriculum planning was influenced by place and encounters with 'more-than-human' elements such as other species, the weather and the challenging terrain (Mannion, Fenwick and Lynch, 2013).

These examples highlight the pedagogical importance of place in outdoor education and learning, but show that theory and research are only beginning to help us understand how place gets harnessed into teaching outdoors. In the next section, we will outline our understanding of place responsive pedagogy, what counts as 'more-than-human', and the connection between these two with the theory and practice of outdoor, environmental and adventure education.

\section{Place-responsiveness and the 'More-than-Human'}

Casey provides a theoretical basis for understanding that all of our lived experiences as humans are place-based (Casey, 1998) and that to survive and adapt as a species on the 
planet we need to respond to the places in which we find ourselves. In a linked manner, continental philosophical understandings of place, especially those within phenomenology (Malpas, 1999) suggest that we come to understand the world through place: "it is, indeed, in and through place that the world presents itself" (ibid, 15). Casey (1998) notes how it is the body that is the source of all experience in space, and it is the movement of that body in space that gives us a way of accessing the world.

The lineage of our term 'place-responsiveness' can be traced back to John Cameron who defined this as the development of "a deep connection with place is an integral element of the culture, enabling us to live sustainably within the environment" (2003; 180). Cameron writes:

\begin{abstract}
Place is not the mere passive recipient of whatever humans decide they wish to do upon the face of it. The land is an active participant in a very physical sense... it [sense of place] includes a growing sense of what the place demands of us in our attitudes and actions. (ibid, 176).
\end{abstract}

We find Cameron's description of the land as an active participant suggestive of a worldview that is not singularly humanistic. Cameron notes that this includes being open to other person's stories of place and the other aspects of place beyond merely the social. In calling us to 'learn' our way via a reciprocal responsiveness between human and place he notes "It is learning how to develop ecological literacy, awareness of the more-than-human aspects of place openness to other stories of place than one's own..." (ibid, 194). In outdoor and environmental education, Mannion, Fenwick and Lynch (2013) have argued that a similarly reciprocal place-responsive approach to pedagogy can be enacted through involving the distinctive elements found in places into events. Place-responsive pedagogy, for them, is based on a dynamic relational view of place and people/place interactions and can involve highly educational encounters with the 
'more-than-human' elements. We explain and explore this term next.

The term 'more-than-human' has a lineage within the phenomenological tradition in education (Abrams, 1996) but has appeared later, with more in-depth explanation, in human geography (Jones, 2013; Whatmore, 2002) and post-humanist accounts of learning (Pederson, 2010). Whatmore's explanation of the 'more-than-human' pushes us to attend to processes and materials beyond the human, yet includes the human in their relations with this materiality of the world and the Earth. Theorising the human and the more-than-human in new ways has consequences for both. Whatmore explains:
...So it is that recent contributions [in the field of cultural geography] have sought to do (at least) three things. The first has been to re-animate the missing 'matter' of landscape, focusing attention on bodily involvements in the world in which landscapes are co-fabricated between more-than-human bodies and a lively earth. The second has been to interrogate 'the human' as no less a subject of ongoing co- fabrication than any other socio-material assemblage. The third in my list has been the redistribution of subjectivity as something that 'does not live inside, in the cellar of the soul, but outside in the dappled world'... This redistribution of energies puts the onus on 'livingness' as a modality of connection between bodies (including human bodies) and (geo-physical) worlds. (2006; 603).

Whatmore's contribution seems to challenge humanistic phenomenological accounts of place, suggesting that such would offer only a partial understanding of how we interact with and through place. Deploying the term 'more-than-human' encourages researchers to notice that any account of people and place cannot be merely a product of solely human actions. Simply put, since we and our environments continually co-specify one another, research should take due account of these place-based, relational and assembling processes and how knowing through these processes arises (Ingold, 2011). By this view, epistemology and ontology are intertwined. Barad uses the term 'ontoepistemology' (Barad 2007) to capture this intertwining of knowing and becoming. As 
an example, Maurstad et al (2013) use Barad's term intra-action to capture how, in their study humans and horses meet each other and are both changed through the process.

We draw upon these concepts of place-responsiveness and the more-than-human in our framing for our research methodology. Our disposition has resonance with emerging post-qualitative positions within the social science (Lather, 2013; St Pierre, 2011, 2014). Some 'post-qualitative' researchers are attempting to operationalize how we conduct research when we take seriously the idea that we are not separate from the world. St Pierre writes that post-qualitative research:
...does not allow the subject/object and human/material oppositions to be thought
or lived. We are not separate from the world. Being, in every sense is entangled, connected, indefinite, impersonal, shifting into different multiplicities and assemblages. (St Pierre, 2014; 226).

The anthropologist Tim Ingold (2000) draws upon Deleuze and Heidegger, to explain further how people-and-place are entangled in assemblages in a contingent unfolding interacting process. Ingold argues that people and places are relationally emergent through the activities of both people and many other entities and processes that allow life to unfold (including the weather, the activities of animals as much as humans) - the 'more-than-human'. Ingold suggests that all living beings act within a unified field of relations within which agency is not located 'in' a person or other entity but is afforded through the connections between the assembled beings.

The consequences for place-responsive research and research on the more-than-human are far-reaching. Researchers must collect data on the many elements which make up these assemblages which can be physical, social, discursive, material, imaginative or cognitive (Renold \& Ivinson, 2014). Research processes themselves are inevitably another form of assembling too which further challenges some conceptualisations of 
objective research. Because research assemblages and those found in the empirical field are changing and unstable, they are continually in a state of becoming different. How we know and what we learn must, therefore, accrue through reciprocal response making by all the entities found within assemblages (see Mannion and Gilbert, 2015). This means that place-responsive research methodologies in outdoor and environmental education need to look at evidence of events that participate in this process of becoming and create changes in the relevant assemblages. In addition, educational researchers working with this theoretical framing need to find ways of noticing when and how these assemblage relations shift and what the effects are on learners and learning.

In this research project, one possible method for data collection emerged as a way of more explicitly acknowledging the issues outlined above: the walking interview. This method is clearly mobile and, as such, was chosen as a way to attend to how the ongoing processes of the assembled elements continued to produce differences. These differences would be experienced through the walking journey by the researcher and the respondents who, in this case, were teachers. The walking interview allowed the researcher to go with the teachers back to the sites in which they had planned and later taught their pupils outdoors. This method proved useful for noticing when and how places came and continued to be enmeshed in the intended and experienced curriculum of outdoor learning but the experiences of walking also threw up some surprises en route which validated the choice to go mobile with data collection. The walking method was one of several methods employed within a wider case study design that also included artefact interviewing, document analysis, situated interviews (in class and school), photography and email journaling. We will show how our approach to walking interviews allowed the researcher to witness the creativity of place-responsive educators as they worked with the realities of their specific emplaced context. The data also show 
how the research process itself can be seen as an event that too unfolds in a placeresponsive manner.

\section{Walking as a Research Method}

Researchers have employed walking interviews for a variety of reasons and in different ways across disciplines. Mostly, researchers justify this mobile method because it reveals more or particular kinds of data connected to the locations visited. For some, it is a question of addressing power dynamics. Sin (2003) found that the spatial aspects of interviewing have not been well attended to in social research and argued that the construction of identities, power and knowledge are in a dialectic with the place of the interview. Carpiano (2009) explored the use of 'go along' interviews in researching the health of places and found the 'go-along' interview helped to increase the participation of the interviewee and highlighted the importance of the context of the research interview. Brown and Durrheim (2009) similarly noticed walking interviews increased rapport because the place itself functioned as a co-producer of dialogue. Walking also affords data collection on sensory and affective elements. Knutz and Presnell (2012) advocate the walking interview to show how the embodied aspects can allow us to capture the spoken and affect data on the unfolding event of the walking practice. With similar sensibilities towards embodied and lived experience, Anderson (2004) argues that the walking interview is a way to excavate the 'co-ingredience' of people and place through the lived experiences of where we act out our lives; in place. Hall, Lashua and Coffey (2008), utilised the 'go-along' interview with young people in their study of noise as part of lived everyday life and movement. Spinney (2015), however notes mobile methods can miss the capture of data that is not 'on the move'.

For our purposes, we wish to provide a particular theoretical platform for our use of the 
walking interview. We have already argued that the human and the more-than-human are best understood as intra-acting within a unified relational field of assembled entities. In this research, we took walking interviews to be an active intervention in the placemaking or place assembling process with a view to understanding the effects of those very processes. Like all approaches, we would argue, different methods will bring different effects on the field of inquiry and influence what is produced through them. We are not alone in advancing a relational approach to place in research. In outdoor education, Mullins (2014) used a form of hermeneutic phenomenology to research the reflective practice of participants on a 100 day wilderness canoe journey. He found that skilled practices, social interaction and environmental conditions were co-influential. Ross, Renold, Holland, and Hillman (2009) used walking interviews - 'guided walks' that were co-created with respondents - arguing that these journeys were themselves place making practices that afforded ways to understand the young people's everyday geographies. Ivinson and Renold (2013) within a multi-method ethnography also used walking and 'situated interviews' to collect data on young peoples' lives and places emphasising how these were open to future becomings and possibilities. In a similar vein, Edensor's (2010) work used walking and place being thought of as 'stretched out' along linear routes focussed on the rhythm of walking and how as a repetitive motion it is a way of thinking and feeling a world 'in formation' $(2010 ; 75)$.

Ingold and Vergunst's (2008) anthropology of walking provides a possible explanation for these distinctive effects of walking as a research tool. Importantly, they see walking - like other practices - as an action that participates in creating a world that is itself already in formation. Walking interviews are one useful and important way of attending to our need as researchers to correspond with the flow of events in a place whilst collecting data in a participatory way. Lund (2012) views landscapes as commonly 
'narrated' through the activity of walking: we make our way through a world-in formation not across the mere top of it. Walker and landscape entwine each other. Ingold (2011) writes that through modernity the focus changed from our apprehending the world through our feet to doing so with our hands and, latterly, with our minds. However, it was and is through our feet that we are most significantly and continuously connected to the world and this reality may be obfuscated by more mentalist constructions of experience. He looks at the process of walking and thinks of walking, reading and writing as interconnected activities; Ingold sees walking as a mental exercise as well as physical and that there is "constant traffic between these terrains [walking and reading], respectively mental and material, through the gateways of the senses" $(2010,18)$. Ingold sees locomotion not cognition as key in actively apprehending and perceiving the world. Thus, in the approach described here, to walk with interviewees, we argue, helps us to correspond with worldly processes they too encounter. All the while, both interviewer and interviewee are apprehending the world as it unfolds and emerges and co-responding to/with it. We seek to document, therefore, how the world is relationally apprehended through the following assembled narrative accounts of human-with-more-than-human intra-actions. These accounts are best seen as productive witness testimonies that will we trust evoke meanings with readers rather than providing one fixed representation of these events.

\section{Method in Practice: Walking Interviews in Place}

The data examples documented in this paper come from an on-going research project on the role of place (with a particular focus on the 'more-than-human' elements) in teachers' planning and enactment of education in outdoor settings. The data here come from a set of five teacher-focused case studies which are seen as place-based 'assemblages'. Each assemblage comprised the teacher, their places for outdoor 
teaching, and the processes they used to plan for this teaching. Each teacher was visited twice to complete walking interviews. This paper shares exemplars from the walking interviews and associated photographs and fieldnotes only though other methods were used in tandem. The walking interviews were arranged so that the educators could take the researcher back to the very places in which they had taken their learners for regular outdoor educational experiences. By default, these were also the places that educators had usually visited ahead of taking their pupils in order to plan the outdoor educational excursions. On these walking interviews, the researcher sought to gain evidence of how the educators went about planning and enacting their teaching and to inquire into when, if and how elements of the place featured in this unfolding process. In this paper, we particularly focus on the ways in which this data collection method allowed for encounters with the more-than-human to be elucidated.

The walking interviews were approximately two hours long and audio recorded throughout. In addition, photos were taken of place elements that were regarded as significant or evoked key past, present, and possible future teaching events. Data came in two related ways. One strand of data was about past events while other data captures unexpected events - for example encounters with animals or their tracks - that transformed the walking interview itself through changing its focus. Walking interviews sought to allow for a degree of correspondence between the researcher and the on-going nature of the respondents' experience of place.

Practically, the researcher found that audio recording and taking photos was challenging despite piloting of the equipment. Yet, using multiple forms of AV equipment whilst on the move provided for an enriching data collection process. Recording equipment used was a Zoom HN4 with windjammer to improve audio quality outside in windy conditions. Audio files were professionally transcribed. Photographs were taken with a 
digital SLR (DSLR) and spare batteries and memory cards were carried. With such burdensome technology, notepads and written prompts were not practical but short fieldnotes were also produced from memory soon after each walk.

\section{Teacher's Planning of Outdoor Learning: Vignettes and Data Examples}

The following data examples are provided as 'vignettes' (Ivinson and Renold, 2013; Masny, 2013a, 2013b). Space here does not permit a fuller explanation but the vignettes shared here are expressions of a post-qualitative orientation towards social science research (See for example Lather, 2013; St Pierre 2014). The vignettes are presented as assemblages (Fox and Aldred, 2014) of transcripts, photographs and fieldnotes, The Vignettes need to be read as an assemblage with the transcripts, field notes and photos working together to portray and disclose meaning. Following Jones (2013) we seek to evoke and portray the evidence gathered in the walking interviews and, in particular, the effects of the more-than-human which emerged as a significant theme in the data analysis process. Vignettes were chosen because of their ability to introduce questions for us as researchers and for subsequent readers of vignettes in the products of research. In the vignette (assemblage) choice and in their reading, we propose that meaning making is ongoing. The usefulness and validity of the vignette is in its ability to bring forth new meanings through being both provocative and productive for any committed reader and for us the researchers. As Masny (2013a) notes on vignettes:

\footnotetext{
It is a process in which there is an investment in reading, reading the world and self. Instead of considering interpretation and what a text means, the questions are what vignettes do and how do they function. (Masny, 2013a: 343)
}

The vignettes are presented along with tentative suggestions (Ivinson and Renold, 2013) for analysis and are chosen for the power we feel they have to evoke, disclose, portray, new ways of understanding. Our vignettes are revealing but seek not to directly 
represent the collective assembled relations among the people involved, their worlds; the human and the more-than-human. We hope the vignettes signpost for readers what might be important about the more-than-human element in planning for outdoor learning in other settings too. Vignettes, then, invite readers into a collaborative witnessing of the role of the more-than-human (mammals, trees, plants, weather) in the planning for outdoor learning. We note how teachers' ability to be place-responsive in planning are connected to teachers' preparedness to notice, address and respond to more-than-human aspects on these walks.

\section{Vignette 1}

The vignettes contain interview transcripts, photos from the walking interview, and field notes. The first vignette is from a walking interview in the local forest behind the school, which is an open and mature Scots Pine plantation. The forest is the main site the teachers use for their regular outdoor learning. The forest is managed for biodiversity by the National Trust for Scotland which includes some active badger setts which are known to the teacher and children. This vignette portrays a surprising encounter with the tracings of the badgers in the forest during a walking interview.

Figure 1 in Text Box

The first vignette portrays how the outdoor place provides a setting for learning that is 
seen by the teacher as being full of varied differences - in this case tree species. In the transcribed text, we hear how the differences in places afford a way of linking the static knowledge - tree identification - to real lived experiences of changing landscape features since they revisit the same site over different seasons. For this teacher, 'knowing that' (static content knowledge) is translated into 'knowing how'. In this case, we can know that in the world something exists as a larch tree, but in practice in a real place, the larch tree can be identified through interactions with the encounter with this more-than-human element. This resonates with Ellsworth's ideas around pedagogy and place where she sees we are not just bodies but bodies "whose movements and sensations are crucial to our understandings" (2005; 27). Paraphrasing Kennedy's work she writes about the way 'bodies' are assembled with the bodies of the users/viewers/ observers; "in a web of inter-relational flows in material ways" (Kennedy, 2003; 26)" $(2005 ; 27)$.

In this account, the presence of badgers impacts on the researcher and a discussion ensues about how the teacher is prepared to work with this new found difference to offer a view on how a new line of inquiry could be initiated with the pupils in ways that might involve new relations with 'experts' beyond the classroom. The teacher's response suggests an orientation to using the traces of the badger as a way of recording and classifying, objectifying the knowledge, seeking 'facts' about what the phenomena might be but locating these explanations in a way that is tied to shared embodied morethan-human encounters in a place they know well.

One reading of these data is that the process of curricular assembling is a collaborative activity involving the agencies of humans and more-than-human elements. Here we see interactions among the badgers, the documents of the official curriculum, the teacher's actions, the pupils' expected participation and the engagements with others beyond the 
school. This suggests place-responsive curricular assembling sets out to afford memorable and meaningful forms of learning through the co-production of knowing through human and more-than-human encounters.

\section{Vignette 2}

In this second vignette, at a different site in Scotland, the story unfolds of how researcher and respondent gained a fleeting glimpse of a Sea Eagle at the end of the walking interview. This occurred at a beach where the teacher hopes to build a bird hide to allow the children to view these birds and other wildlife.

Figure 2 in Text Box

This vignette portrays how the more-than-human in the environs of this particular Island school and local area are experienced as intertwined with the process of planning for outdoor learning. As Ingold might put it, we see that the teacher seeks to correspond with the habits and trajectories of other species. Corresponding with the more-thanhuman, she uses certain sites and places because they have potential for animal and bird sightings she wants the children to see. This correspondence with the more-than-human extends to her actions and desires to build a bird hide with the help of local experts in order to see more wildlife with the children. The walking interview provides 
opportunities for collecting data on the way the raptors in this place seem to nudge the curriculum making of teachers, the children, and locals in particular directions. This vignette in particular, with the Sea Eagle appearing just as we were leaving the site, is an example of the chance encounters, the fleeting contingent unplanned glimpses that outdoor sites like these offer.

How educators respond and prepare to respond to contingent place experiences seems very important here. Critically, perhaps, this teacher welcomes this potentiality in her practice. Also relevant are her local place knowledge and the efforts made to make repeat visits which enable the teacher's correspondence with the more-than-human and her attunement to place to be honed. Place-responsiveness through attending to the more-than-human is not merely an outdoor concern. The silhouettes on the roof of the classroom (see field notes) in this vignette remind us of the connected nature of indoor and outdoor places connecting a sequence of activities that might afford learning through responding with and to the more-than-human and the landscape around the school.

Openness to the alterity of the more-than-human and the generation of deep place knowledge over time seem necessary for this teacher to be able to respond to the morethan-human in ways that are interwoven into the planned pedagogical experience of landscape. Wattchow and Brown (2011) identify that if we are to harness place pedagogically then as educators we are required to have "a sense of timing and a feel for the possibilities in our immediate surrounds" $(2011 ; 185)$. This vignette suggests that some encounters with the more-than-human - perhaps especially so when outside the classroom - are more likely when one is on the move. Encounters were fleeting and involved noticing the subtle traces. Our sense is that a teacher's expertise includes a keenness to learn about where to look as well as what to look for ahead of 
considerations about how to work with these experiences. The walking interview afforded opportunities to witness the dispositions and orientations of the educator when attempting to educate with and in a world that is in formation, and their efforts to harness their effects into an unfolding process of curriculum making.

\section{Vignette 3}

This last vignette focuses on the events that transpired near some disused and overgrown curling ponds the teacher found when she was with the children at their local outdoor learning area of semi-natural woodland. The assembled vignette evidence portrays the nature of reciprocal responsiveness among various becomings over time: children-place, teacher-children, and teacher-place.

Figure 3 in Text Box

This vignette portrays how the more-than-human possibilities in the place were able to change the course of an outdoor learning session. We see how the teacher explains how she changed her enactment of outdoor learning because of the frogs and how she saw this as still a successful educational encounter. These data disclose how the educational potential of the more-than-human in outdoor learning is harnessed in part, through how the teacher herself is again, attuned to place. In addition, we see how in terms of curriculum making this teacher is open to responding to the place through the children and how the children were fascinated by the ruins at the old curling pond. Catling's 
(2013) empirical work with the primary school geography curriculum notes how children have their own 'geographies' that teachers can harness into a concern with places in their curriculum making. We notice that teacher's responses to place are in part generated through their concern for children's interests and their interactions with more-than-human entities found within place. This intertwining of the more-thanhuman and the pupils, the frogs and the curriculum are an example of the assembling forces we understand to be at work. The walking interview as method allowed for glimpses of this assembling process and how teachers disclosed their practice of curriculum making as part of such an assemblage. This vignette indicates the nuanced nature of teacher's responsiveness to place and how 'in the moment' a given response to the more-than-human unfolds in the world and generates pedagogical implications.

These data, as we interpret them, tell us that curriculum making is an eco-social material practice. It involves teachers responding to places that change over time, with the other species found there, with the effects of the seasons and with the weather. In turn, these places change in response to the place-making activities of children and the teacher: planting, picking, hiding, climbing.

\section{Walking Interviews: Empirical Research and Our Approach}

These vignettes show the potential in the methodology and walking interview method described in capturing evidence of place-responsive correspondences with the morethan-human. The walking seemed to open up the teachers' thinking and afforded opportunities for agencies of the more-than-human in place to co-produce the evidence used above. The materials and features of the outdoors as we walked became relevant to the discussions; it seemed we both (interviewee and respondents) came to pay attention to the more-than-human (ecological and other material) aspects that may have been 
forgotten in a more sedentary interview based indoors. Ingold calls this knowledge creation through movement in the world "wayfaring" $(2011 ; 148)$. For Ingold, it is less that place itself (as container or context) is important than the movement through/along places "The path, and not the place, is the primary condition of being, or rather of becoming" $(2011 ; 12)$. We see the importance of the path, the walking, as an important way of understanding how we come to know the world. Sharing this walk with the teachers and setting out to encounter the place as a site of practice and possibilities is where we see the richness in this method. Critically there are practices and knowledges that are not place based that we missed and did not pay attention to. Although Ingold argues that it is in moving through the world (wayfaring) that knowledge is created "scientific knowledge, as much as the knowledge of inhabitants, is generated within the practices of wayfaring" $(2011 ; 155)$ for us we acknowledge that we are in some ways privileging the place-responsive practice knowledge that this method collected data on. We acknowledge that in these data examples, we have privileged the way the teachers were seeking to move with the flow of knowing that was enfolded with and through the processes of place making. They had come to know and understand the nature of planning for and enacting place-responsive curriculum making through their on-going 'apprenticeship' (Wattchow \& Brown, 2011) to particular places.

As we have framed it and deployed it, we suggest that the walking interview is a very legitimate method to research these relations and the method produces one viable way of noticing our participation in places including how we come to know through them. As a tool, we suggest, these kinds of walking interviews and data analysis can help to overcome some of the challenges of representation that exist in how we ontologically understand nature (Castree, 2004; Thrift, 2006). We consider this approach to be one response to the call to be more sensitive to the challenge of apprehending the world 
(rather than fixedly representing it) because it and the research process are both in flow (Hall, 2009; Shelley and Urry, 2006).

In our vignettes, we noticed how the more-than-human came to be an important part of what was noticed and harnessed by the teachers. Some of these teachers were only somewhat self-aware of these processes. Some more actively sought to harness the more-than-human into their pedagogies. Hincliffe, Kearens, Degan and Whatmore (2005), and Ingold (2000) suggest there are quite diffuse boundaries between the 'human' and 'animal'. Based on our evidence, education in outdoor settings is likely to require more explicit acknowledgement of the more-than-human in teacher education and in-service professional development.

We are finding walking interviews are a useful approach to use to collect data to understand the role of the more-than-human in teachers' planning and enactment of outdoor learning. Data from walking interviews helped us correspond to how the teachers saw, experienced and responded to a world that was in flow or in formation. The teachers' commentaries and responses to the event of the walking interview helped us understand how they were disposed to and encouraged their learners to utilise experiences of places to gain new understandings. The data analysis supported the view that for some teachers, knowing and becoming with and in place could viably be intertwined within formal educational experience outdoors; their approaches to planning and curriculum making showed sensitivity to learning as a process that emerged with and through the flow of place.

\section{Conclusion}

Educational practitioners can be key players in the assembling of place-responsive curriculum making. To do so we need to know how the more-than-human is to be 
noticed, attuned to and harnessed within the assembling learners, technologies, formal curriculum intentions and place elements: "Practitioners, I content, are wanderers, wayfarers, whose skill lies in their ability to find the grain of the world's becoming and to follow its course whilst bending it to their evolving purpose" (Ingold 2011; 211). Mannion, Fenwick and Lynch (2013) found that teachers consider place in planning outdoor learning to various degrees: they can be place-ambivalent, place-sensitive, or place-essential. In practice, being assembled with and in a place is unavoidable whether indoors or out. But being open to, noticing and harnessing the agencies of relations with others and with the more-than-human is undoubtedly a key disposition for educators in outdoor places. We suggest that this will be increasingly important if we are to use place-based experiences to understand and improve human-environment relations. In these cases, we notice how the teachers who developed this disposition to a greater degree were also the ones who had spent considerable amounts of time outdoors, had on-going connectedness with other local people and experts, and importantly, were able to enlist the agencies related to the more-than-human into their plans and pedagogies

These findings suggest there is more to learn about how places can be harnessed effectively into place-responsive pedagogy especially when outdoors. We argue that using a place-responsive methodology is one way to significantly contribute to this in research. But our experience also suggests that many different methods would likely be differently evocative yet just as revealing. Using a walking interview method we were able to gain some understanding into the what, and the how, of a teacher's educational planning when taking their pedagogy outdoors, and how the more-than-human were part of that encounter.

We have explored one line of thinking that allows us to make claims on the importance of place in outdoor educational provisions. We have suggested, in addition, that this 
onto-epistemological framing of knowing through wayfaring is suggestive of a need to respond differently to place in the ways we teach outdoors and research outdoor experience and outdoor education. We have exemplified our methodological position and described one way of conducting empirical data collection and analysis that takes these ontological concerns seriously. The walking interview method is but one of a range of emerging ways of responding to the problems of representation.

New research methods and methodologies are needed to be open to registers of meaning that are not limited by the dominance of the human or merely cognitive processes. Going forward, we suggest place-responsive research methodologies will benefit from an experimental approach. Whatmore identifies a challenge, and requirement, of research orientated towards the more-than-human is to be able to experiment and take risks - especially in methods. She calls for a breakaway from humanist methods of talk and text and a move towards other "that amplify other sensory, bodily and affective registers and extend the company and modality of what constitutes a research subject." $(2004 ; 1362)$

In the developing fields of outdoor education, adventure education and outdoor learning the walking interview as described here and other methods have great potential in encouraging ways of allowing for the more-than-human elements to be implicated in research processes. In the outdoors we are very often 'on the move', whether it is within an adventurous activity, on journeys or expeditions, or indeed, in urban settings. Placeresponsive research methodologies can help deepen our understanding of how the significance of being outdoors impacts on planning for learning and the ongoing flow of pedagogical decision making. We advocate for further advances in place-responsive research to help deepen our understanding of how outdoor places of all kinds are educationally distinctive 


\section{References}

Abrams, D. (1996). The spell of the sensuous: Perception and language in a more-thanhuman world. New York: Random House Publishing.

Anderson, J. (2004). Talking whilst walking: A geographical archaeology of knowledge. AREA, 36 (3), 254-261.

Ardoin, N. (2006). Towards an interdisciplinary understanding of place: Lessons for environmental education. Canadian Journal of Environmental Education, 11, 112-126.

Ardoin, N., Schuh, J., \& Gould, R. (2012). Exploring the dimensions of place: A confirmatory factor analysis of data from three ecoregional sites. Environmental Education Research, 18, 583-607.

Ballantyne, R., \& Packer, J. (2002). Nature based excursions: School students' perceptions of learning in natural environments. International Research in Geographical and Environmental Education, 11(3), 219-236.

Ballantyne, R., \& Packer, J. (2006). Promoting learning for sustainability: Principals and perceptions of the role of outdoor and environmental education centres. Australian Journal of Environmental Education, 22, 1-15.

Ballantyne, R., \& Packer, J. (2009). Introducing a Fifth Pedagogy: Experience-based strategies for facilitating learning in natural environments. Environmental Education Research, 15(2), 243-62.

Barad, K. (2007). Meeting the universe halfway: Quantum physics and the entanglement of matter and meaning. Durham: Duke University Press.

Beames, S., Higgins, P., \& Nicol, R. (2012). Learning outside the classroom. London: Routeledge. 
Bentsen, P., Mygind, E., \& Randrup, T. (2009). Towards and understanding of Udeskole: Education outside the classroom in a Danish context. Education 3-13, 37(1), 29-44.

Brookes, A. (2002). Lost in the Australian bush: Outdoor education as curriculum. Journal of Curriculum Studies, 34(4), 405-425.

Brown, L. \& Durrheim, K. (2009). Different kinds of knowing: Generating qualitative data through mobile interviewing. Qualitative Inquiry, 15, 911-930. doi: $10.1177 / 1077800409333440$.

Brown, M. (2012). Student perspectives of a place-responsive outdoor education programme. New Zealand Journal of Outdoor Education, 3(1), 64-88.

Cameron, J. (2003). Responding to place in a post-colonial era: An Australian Perspective. In W. Adams, \& M. Mulligan (Eds.), Decolonising nature: Strategies for conservation in a post-colonial era (pp. 172-196). London: Earthscan.

Carpiano, R. (2009). Come take a walk with me: The "Go-Along" interview as a novel method for studying the implications of place for health and well-being. Health and Place, 15, 263-272.

Casey, E. (1998). The fate of place: A philosophical History. London: University of California Press.

Catling, S. (2013). Teacher's perspectives on curriculum making in primary geography in England. Curriculum Journal, 24, 427-453. doi: 10.1080/09585176.2013.801781.

Castree, N. (2004). Nature. London: Sage. 
Cosgriff, M., Legge, M., Brown, M., Boyes, M., Zink, R. \& Irwin, D. (2012). Outdoor learning in Aotearoa New Zealand: Vices past, present and future. Journal of Adventure Education and Outdoor Learning, 12(3), 221-235.

Edensor, T. (2010). Walking in rhythms: Place, regulation, style and the flow of experience. Visual Studies, 25(1), 69-79.

Ellsworth, E. (2005). Places of learning: Media, architecture, pedagogy. Abingdon: Routeledge.

Fox, N. \& Alldred, P. (2014). New materialist social inquiry: Designs, methods and the research-assemblage. International Journal of Social Research Methodology, 18 , 399-414. doi: 10.1080/13645579.2014.921458

Gruenewald, D. (2003a). Foundations of place: A multidisciplinary framework for place-conscious education. American Educational Research Journal, 40(3), 619654.

Gruenewald, D. (2003b). The best of both worlds: A critical pedagogy of place. Educational Researcher, 32(4), 3-12.

Gruenewald, D. \& Smith, G. (2008). Place-based education in the global age. Adingdon: Taylor and Francis.

Hall, T., Lashua, B., \& Coffey, A. (2008). Sound and the Everyday in Qualitative Research. Qualitative Inquiry, 14, 1019-1040.

Hall, T. (2009). Footwork: Moving and knowing in local space(s). Qualitative Research, 9, 571-585.

Harrison, S. (2010). Why are we here? Taking place into account in UK outdoor environmental education. Journal of Adventure Education and Outdoor Learning, 10, 3-18.

URL: http://mc.manuscriptcentral.com/raol 
Higgins, P., \& Wattchow, B. (2012). The water of life: Creative non-fiction and lived experience on an interdisciplinary canoe journey on Scotland's River Spey. Journal of Adventure Education \& Outdoor Learning, 13, 18-35.

Hinchliffe, S., Kearnes, M., Degen, M., \& Whatmore, S. (2005). Urban wild things: A cosmopolitical experiment. Environment and Planning D: Society and Space, 23, 643-658.

Ingold, T. (2000). The perception of the environment: Essays on livelihood, dwelling and skill. Abingdon: Routeledge.

Ingold, T. (2010). Ways of mind-walking: reading, writing, painting. Visual Studies, 25(1), 15-23.

Ingold, T. (2011). Being Alive; essays on movement, knowledge and description. Oxon: Routeledge.

Ingold, T. \& Vergunst, J. (Eds). (2008). Ways of Walking: Ethnography and Practice on Foot. Aldershot: Ashgate.

Ivinson, G., \& Renold, E. (2013). Valleys' girls: Re-theorising bodies and agency in a semi-rural post-industrial locale. Gender and Education, 25, 704-721.

Jones, O. (2013). “Who Milks the Cows at Maesgwyn?”: The Animality of UK Rural Landscapes in Affective Registers. Landscape Research, 38, 421-442. doi: 10.1080/01426397.2013.784246.

Knutz, A., \& Presnall, M. (2012). Wandering the Tactical: From interview to Intraview. Qualitative Inquiry, 18, 732-744.

Lather, P. (2013). Methodology-21: What do we do in the afterward? International Journal of Qualitative Studies in Education, 26 (6), 634-645 doi: 10.1080/09518398.2013.788753. 
Lund, K. (2012). Landscapes and Narratives: Compositions and the Walking Body. Landscape Research, 37 (2), 225-237.

Malpas, J. (1999). Place and Experience: A philosophical topography. Cambridge: Cambridge University Press.

Mannion, G., Fenwick, A., Nugent, C., \& I'Anson, J. (2011). Teaching in Nature (Report No 476). Retrieved from Scottish Natural Heritage: http://www.snh.org.uk/pdfs/publications/commissioned_reports/476.pdf

Mannion, G., Fenwick, A., \& Lynch, J. (2013). Place-responsive pedagogy: Learning from teachers' experiences of excursions in nature. Environmental Education Research. 19, 792-809.

Mannion, G., \& Lynch, J. (2016). Primacy of Place in Education in Outdoor Settings. In B. Humberstone, H. Prince \& K. Hendersen. (Eds.), Routeledge International Handbook of Outdoor Studies (pp 85-94). Abingdon: Routeledge

Mannion, G. \& Gilbert, J. (2015). Intergenerational Space. In R. Vanderbeck, \& N. Worth (Eds.), Routledge Studies in Human Geography (pp. 228-242). London: Routledge.

Masny, D. (2013a) Rhizoanalytic Pathways in Qualitative Research. Qualitative Inquiry, 19(5), 339-348. doi: 10.1177/1077800413479559.

Masny, D. (2013b). Becoming thousand little sexes: This is not my father's paradigm. In, D. Masny (Ed.), Cartographies of Becoming in Education: A DeleuzeGuattarian Perspective (221-235). Rotterdam, Sense Publishers.

Meichtry, Y., \& Smith, J. (2007). The impact of a place-based professional development program on teachers' confidence, attitudes and classroom practices. The Journal of Environmental Education, 38(2), 15-31. 
Mullins, P. (2014). Conceptualizing skill within a participatory ecological approach to outdoor adventure. Journal of Experiential Education. 37(4). 320-334.

Maurstad, A., Davis, D., \& Cowles, S. (2013). Co-being and intra-action in horsehuman relationships: A multi-species ethnography of be(com)ing human and be(com)ing horse. Social Anthropology, 21, 322-335.

Mygind, E. (2009). A comparison of children's statements about social relations and teaching in the classroom and in the outdoor environment. Journal of Adventure Education and Outdoor Learning, 9(2), 151-169.

Nespor, J. (2008). Education and place: A review essay. Educational Theory, 58(4), 475-489.

Pederson, H. (2010). Is 'the posthuman' educable? On the convergence of educational philosophy, animal studies, and posthumanist theory. Discourse: Studies in the Cultural Politics of Education, 31(2), 237-250.

Quay, J., \& Seaman, J. (2013). John Dewey and Education Outdoors: Making Sense of the 'Educational Situation' through more than a Century of Progressive Reforms. Rotterdam: Sense Publishers.

Renold, E., \& Ivinson, G. (2014). Horse-girl Assemblages: towards a posthuman cartography of girls' desire in an ex-mining valleys community, Discourse: Studies in the Cultural Politics of Education, 35 (3), 361-376.

Ross, J., Renold, E., Holland, S., \& Hillman, A. (2009). Moving stories: Using mobile methods to explore the everyday lives of young people in public care, Qualitative Research, 9, 605 -623.

Shelly, M. \& Urry, J. (2006). The new mobilities paradigm. Environment and Planning A, 38, 207- 226 . 
Sin, C. (2003). Interviewing in place: the socio-spatial construction of interview data. AREA. 35 (3), 305-312.

Smith, G., \& Sobel, D. (2010). Place and community based education in schools. Abingdon: Routledge.

Somerville, M., Power, K., \& De Cartet, P. (Eds). (2009). Landscapes and learning place studies for a global world. Monash University Australia: Sense publishers.

Somerville, M., Davies, B., Power, K., Gannon, S., \& De Carteret, P. (Eds). (2011). Place Pedagogy Change. Rotterdam: Sense.

Spinney, J. (2015). Close encounters? Mobile methods, (post) phenomenology and affect. Cultural Geographies. 22 (2), 231-246.

Stewart, A. (2004). Canoeing the Murray River (Australia) as Environmental Education: A tale of two rivers. Canadian Journal of Environmental Education, 9, 136-148.

Stewart, A. (2008). Whose place, whose history? Outdoor environmental education pedagogy as 'reading' the landscape. Journal of Adventure Education and Outdoor Learning, 8(2), 79-98.

St. Pierre, E. (2011). Post-qualitative research: The critique and the coming after. In N. Denzin \& Y. Lincoln (Eds.), The handbook of qualitative research (4th ed., pp. 611-635). Thousand Oaks, CA: Sage.

St Pierre, E. (2014). A brief and personal history of post-qualitative research: towards post inquiry. Journal of Curriculum Theorizing. 30 (2), 2-19

Szezcepanski, A. (2012). The importance of place for learning and teaching - an outdoor educational perspective. Paper presented at the 6th International Conference on Monitoring and Management of Visitors in Recreational and Protected Areas: Outdoor Recreation in Change - Current Knowledge and Future Challenges, Stockhom, Sweden. 
Thrift, N. (1999). Steps to an Ecology of Place. In Massey, D., Allen, J. \& Sarre, P. (Eds.), Human Geography Today (pp. 295-323). Cambridge: Polity Press.

Thrift, N. (2006). Re-animating the place of thought: Transformations of spatial and temporal description in the twenty-first century. In A. Amin, \& S. Roberts (Eds.), Community, Economic Creativity, and Organization (pp. 90-119). Oxford: Oxford University Press.

Tooth, R., \& Renshaw, P. (2009). Reflections on Pedagogy and Place: A journey into learning for sustainability through environmental narrative and deep attentive reflection. Australian Journal of Environmental Education, 25, 95-104

Urry, J. (2007). Mobilities. London: Polity Press

Waite, S. (ed). (2011). Children Learning Outside the Classroom: From birth to eleven. London: Sage.

Wattchow, B.,\& Brown, M. (2011). A Pedagogy of Place. Clayton: Monash University Publishing.

Whatmore, S. (2002). Hybrid Geographies: Natures, cultures, places. London: Sage

Whatmore, S. (2004). Humanism's Excess: some thoughts on the 'post -human/ist' agenda. Environment and Planning A, 36, 1360-1363.

Whatmore, S. (2006). Materialist returns: practising cultural geography in and for a more-than-human world. Cultural Geographies, 13, 600-609.

Woodhouse, J., \& Knapp, C. (2000). Place-Based Curriculum and Instruction: Outdoor and Environmental Education Approaches. Retrieved from: http://www.ericdigests.org/2001-3/place.htm 


\section{Walking Interview Transcript Excerpt}

Interviewer. So what would be distinct about what you might do here?

Respondent Well if you are doing tree ID, they all know about larch, and we have got little rhymes that we know about different trees, so larch is lumpy, lumpy larch and so ... if you are going to do larch you are not going to sit with a smart board with pictures of larch, going "this is a larch tree". You come up here for a walk and you do your tree ID. They only know three or four but that is something you should do up here. But if it is like a measuring activity on metres and half metres which you could do on school grounds, there is not a lot of point. I am not saying there is not a lot of point coming up here, but I think that the place does matter and there is so much variety that we have got. We have got a massive site. We come down here a lot because ... this is our ... down here you will ...

[Interviewer - looking down at my feet, I notice these marks on the ground - see picture]

I. Is that badgers?

I Is it hoof prints? Or noses?

$\mathbf{R} \quad$ Nose marks. This is really far from the sett.

I If you came across that with the children, would you talk about it?

$\mathbf{R} \quad$ We would stop and ask and we use photography so that if we don't have an expert or don't have a definite answer we can take it back and we email.

\section{From Researcher Field Notes (Post Walking Interview)}

The way I started to talk about the research project in the middle of the interview seemed to change the mood - lighten it up a bit. Also the walking and the 'take me on a tour' approach seemed to bring immediate place features/events to our attention so that we could talk about them and the implications for curriculum planning and enactment. The place aspects were more than about memory, it felt that we could talk about things that are not yet fully expressed or used in these processes of curriculum planning and enactment such as the badger nose snouts and the telephone mast. And the last point about how she sensitises the children to the wood - at that point she looked at the wood in a puzzled way...

Getting behind the planning is hard work

She doesn't tell the story of the place very well...there is a lot going on with the different narratives. The interview process was helped by me interjecting with my thinking and aims...the place walking interviews acts as a stimulus -so does the material and the morethan-human .

\section{Photograph 1- Badger nose marks from Walking Interview}

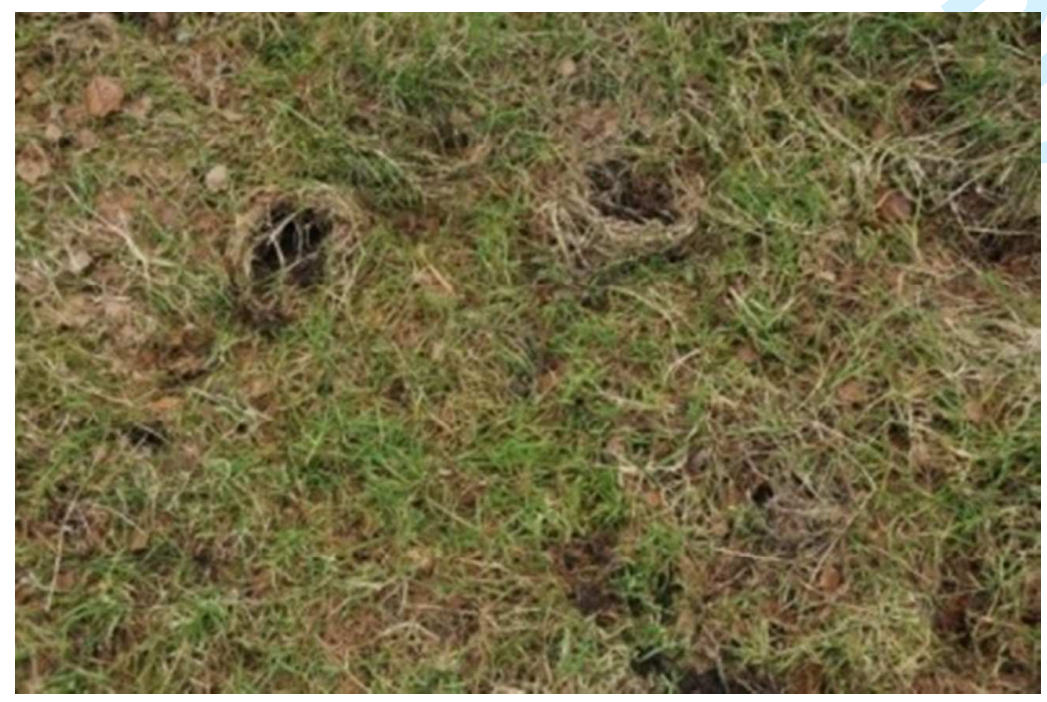




\section{Walking Interview Transcript Excerpt}

Respondent. We have seen different kinds of wildlife. Birds particularly. The other side of here, I am not going to take you there now because it would actually be too far. The other side of this site, there is an old boathouse. And we are hoping with the aid of the local bird club to make that into a sort of bird hide.

Interviewer. Good

$\mathrm{R} \quad$ And it looks out over the estuary. Over the beach. I will show you as we are going back. That again is another area that we are going ... for bird watching and looking more at the bird life around here and hopefully we might see some otters as well while we are here.

I The eagles are impressive. I have seen a sea eagle once before. An amazing bird.

$\mathrm{R} \quad$ Well as you are driving back, have a wee look ... from our school window we see Sea eagles, we see Hen Harriers, there was a Hen Harrier just earlier this morning out there. We see lots of lapwings and Canada geese, and Grey Lag Geese and ... just in the field opposite. The kids are quite ... we did the big bird watch this year and we were lucky enough to be able to put a Hen Harrier on ...

\section{Photograph 2 - Fleeting Glimpse of Sea Eagle}

\section{From Researcher Field Notes}

On the return to the school, in the main classroom there was the huge view out of the window looking east to Ben [mountain]. On the classroom ceiling there were three black life-sized paper silhouettes of three raptors: Hen Harrier, Buzzard and a Sea Eagle, in size order. These were for the children to look up at and compare the bird sizes to each other and themselves.

Is this the outdoors, the more-than-human, leaking into the classroom? Why choose raptors? I think because they are significantly rich life forms in terms of education and examples of the wonderful nature here - and that the outdoors, the more-than-human aspects of place are 'leaking' indoors. Using Ingold (2010) I could understand these in two particular ways. One, as an example of a line of life/living, the livingness of the Raptors that includes their life in the wild and the way that flows back into the classroom via the black paper and the silhouettes on the roof. Secondly, that though the making of these paper silhouettes the people who made them (teachers and pupils?) would have been haptically exploring the form, shape and size of the birds.

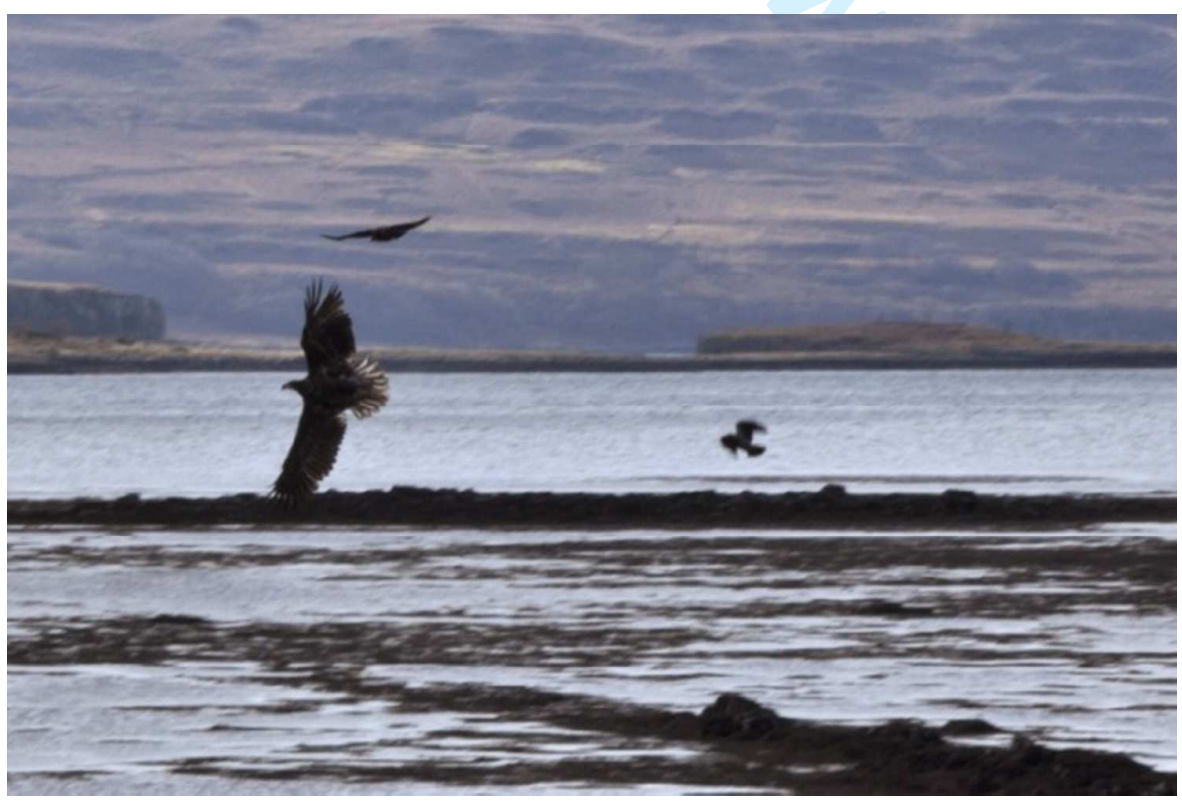




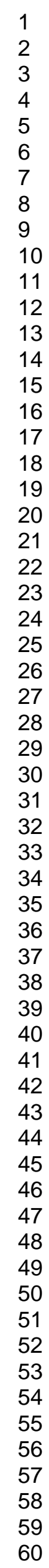




\section{Transcript Excerpt from Walking Interview}

Respondent. Even just walking up this kind of area, it is all boggy and there is lots of frogs and things in the spring time. I did take the class up there and we went looking for plants and we ended up finding more frogs and having a much more interesting time looking for frogs. I think that might be something to do with the curling pond. I don't know.

Interviewer. The curling pond is up there?

R. ...As you can see this is the building that fascinated them. Whether it was a hut for the curling stones, and whether this boggy area was the original curling area, it could be. From the shape of the landscape. I think this is the area the community are suggesting that they re-dig out the pond and use it for pond dipping and if it does freeze over in winter, which it certainly wouldn't have done this winter, it could be used for community curling. It is a stone's throw from the school, I could be up here every day if I wanted to in the spring time. And there is certainly a lot of frogs in that boggy area. Plants got ditched for the frogs. But that is learning as well.
I You turned up here with an idea of doing plants and ...

R We did, we did do a lot with the plants, and the kids recording them with a digital camera and then if you are familiar with the great plant hunt, you go back to school and you load up the photographs, and you look at ... it is the Kew Gardens website ...

\section{From Researcher Field notes.}

The curling ponds were part of a collaborative project where the children and Teacher D discovered them togetherthey went to look at plants but found frogs and that started a trajectory of looking at frogs and the site as a past communal curling pond, now overgrown.

She really sounds very responsive and talked about the places giving her ideas as she goes and responding to wildlife (frogs in the curling pond). One other significant point is that she says she needs to sensitise pupils to the outdoor areas as these are not really outdoor children and on first forays outdoors they just went giddy and scattered.

\section{Photograph 3 - Building at Old Curling} Pond

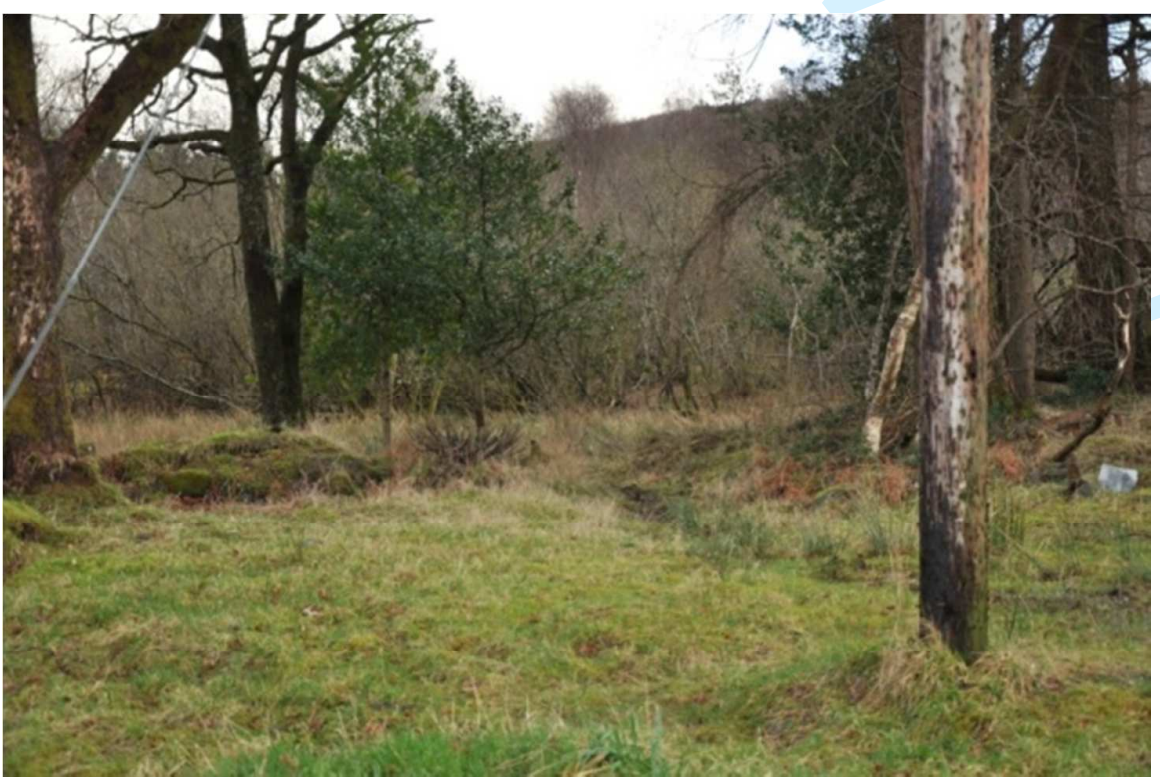




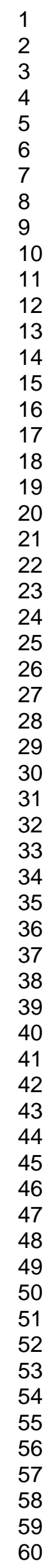

